\title{
$\beta$-Glucosylated proteins in the cell wall of the black yeast Exophiala (Wangiella) dermatitidis
}

\author{
Roy C. Montijn, ${ }^{1}$ Patricia Van Wolven, ${ }^{1}$ Sybren De Hoog ${ }^{2}$ \\ and Frans M. Klis ${ }^{1}$ \\ Author for correspondence: Roy C. Montijn. Tel: +31 205257843 . Fax: +31 205257834. \\ e-mail:montijn@bio.uva.nl
}

1 Institute of Molecular Cell Biology, University of Amsterdam, Biocentrum Amsterdam, Kruislaan 318, 1098 SM Amsterdam, The Netherlands

2 Centraalbureau voor Schimmelcultures, PO Box 273, Baarn, The Netherlands

\begin{abstract}
Wild-type cells of the pathogenic black yeast Exophiala (Wangiella) dermatitidis grown in a low-pH ascorbate medium became less melanized and less resistant to Zymolyase. This was accompanied by increased staining with fluorescently labelled concanavalin A. The sugar composition of wild-type and mutant cell walls was, except for the presence of galactose, similar to that of Saccharomyces cerevisiae. Digestion of mutant cell walls with laminarinase released galactomannoproteins. In addition, the released cell wall proteins contained glucose and reacted with affinity-purified 1,6- $\beta$-glucan antiserum, indicating that they are linked to $1,6-\beta$-glucan. It is proposed that 1,6- $\beta$ glucosylated cell wall proteins generally occur among ascomycetes.
\end{abstract}

Keywords : cell wall proteins, $1,6-\beta$-glucan, galactomannoproteins, black yeast, Exophiala dermatitidis

\section{INTRODUCTION}

Exophiala (Wangiella) dermatitidis, a black yeast with affinity to the ascomycete family Herpotrichiellaceae, is an uncommon agent of (sub)cutaneous mycoses and deep mycoses. Traumatic mycoses result from contaminated materials from the environment (Crosby et al., 1989). The infection route of systemic mycoses is presently unknown. Two prevalent types have been reported: (i) subclinical colonization of the lungs of patients with cystic fibrosis (Haase et al., 1991; Kusenbach et al., 1992), and (ii) neurotropic dissemination (Hohl et al., 1983; Matsumoto et al., 1984), mostly in otherwise healthy patients. The latter clinical type has hitherto been found in Asia only (Hiruma et al., 1993; Matsumoto et al., 1993). Systemic dissemination in European patients with impaired natural immunity is transient, without causing any major disorder (BlaschkeHellmessen et al., 1994; Kabel et al., 1994). The two types of systemic mycoses are caused by strains which are indistinguishable from each other, and therefore the possibility of racial host factors has been surmised (Uijthof et al., 1994).

The cell wall has been proposed to play a significant role

Abbreviations: ConA, concanavalin $A_{;}$GN, glucosamine/Nacetylglucosamine; Endo $H$, endoglycosidase $H_{;}$FITC, fluorescein isothiocyanate; SG, Sabouraud glucose. in the pathogenicity of black yeasts. The presence of melanin and carotene in the cell wall protects the organism against environmental stress, such as dehydration and UV irradiation (Geis \& Szaniszlo, 1984), but also against the oxygenic burst of mammalian phagocytes. In addition, melanin plays a role in resistance against cell wall lytic enzymes, for example chitinase and 1,3- $\beta$ - and 1,6- $\beta$-glucanase (Taylor et al., 1987; Polak, 1989; Dixon et al., 1991). Dixon et al. (1987, 1992) found that melanized strains are more virulent than non-melanized mutants. However, factors other than melanin must also be involved, since nonmelanized mutants remain pathogenic to some extent (Dixon et al., 1987, 1989; Polak \& Dixon, 1993).

In Saccharomyces cerevisiae, about $50 \%$ of the cell wall dry weight is accounted for by mannoproteins, and the other $50 \%$ is composed of $\beta$-glucans and a small amount of chitin (Fleet, 1991; Klis, 1994). The $\beta$-glucans can be subdivided into $1,3-\beta$-glucan $(80 \%)$ and $1,6-\beta$-glucan $(20 \%)$ (Fleet, 1991). The $1,3-\beta$-glucan gives the cell wall its strength, forming a network in which proteins are anchored. Mannoproteins are of two types: the SDSextractable mannoproteins, which are loosely associated with the 1,3- $\beta$-glucan network (Zueco et al., 1986; Hård et al., 1989; Herscovics \& Orlean, 1993) and the SDSresistant glucanase-extractable mannoproteins, which can only be released from the wall by digestion with $1,3-$ $\beta$-glucanases (Pastor et al., 1984), and mostly carry $N$ and/or $\mathrm{O}$-glycan side-chains. The $\mathrm{O}$-linked glycans are 
short linear chains consisting of between one and five mannose residues linked to serine or threonine (Herscovics \& Orlean, 1993). The $N$-linked glycans consist of a chitobiose unit linked to asparagine, elongated with up to 150-200 mannose residues (Ballou, 1990). A third type of carbohydrate side-chain containing 1,6- $\beta$-linked glucose residues and 1,6- $\alpha$-linked mannose residues has recently been described (van Rinsum et al., 1991; Montijn et al., 1994). These 1,6- $\beta$ glucan-containing side-chains were insensitive to endoglycosidase $\mathrm{H}$ treatment or $\beta$-elimination, indicating that they were distinct from $\mathrm{N}$ - and $\mathrm{O}$-glycan sidechains. Recently, it was demonstrated that $1,6-\beta$-glucan chains are cross-linked to $1,3-\beta$-linked glucose residues (Kapteyn et al., 1995, 1996). In S. cerevisiae, the cell wall proteins $\alpha$-agglutinin, Cwp1p and Tip1p have been shown to be 1,6- $\beta$-glucosylated. These proteins are all rich in serine/threonine and contain a glycosylphosphatidylinositol (GPI) attachment signal (Lu et al., 1995; Van der Vaart et al., 1995). It is believed that the $1,6-\beta$-glucan side chain is linked to the protein through the GPI-anchor (Kapteyn et al., 1994; Lu et al., 1994; Kapteyn et al., 1996). Lu et al. (1995) have shown that $1,6-\beta$-glucan becomes attached to $\alpha$-agglutinin upon incorporation into the cell wall. Attachment of $1,6-\beta$ glucan to proteins is a prerequisite for their incorporation in the cell wall (Van Berkel et al., 1994), which in turn is essential for cell viability (Roemer et al., 1993).

In $E$. dermatitidis, $\alpha$-mannan, $\beta$-glucan and chitin are present in the cell wall (Geis, 1981; Szaniszlo et al., 1983). $\alpha$-Mannan is present in the outer layer, while $\beta$ glucan is generally distributed over the cell wall. $\beta$ Glucan appears at least to a large extent to consist of 1,3- $\beta$-glucan, because melanin-deficient mutants (Taylor et al., 1987) and cells albinized with tricyclazole (Dixon et al., 1991) proved to be sensitive to Zymolyase, a 1,3$\beta$-glucanase. In this paper we show that wild-type cells of $E$. dermatitidis grown in low-pH ascorbate medium became less melanized and less resistant to Zymolyase. In addition, we show that cell walls of $E$. dermatitidis are similar to those of $S$. cerevisiae, both in sugar composition and with respect to the presence of $1,6-\beta$ glucosylated cell wall proteins.

\section{METHODS}

Yeast strains and growth conditions. E. dermatitidis (CBS 207.35) was obtained from the Centraalbureau voor Schimmelcultures, Baarn, the Netherlands. Cells were grown in liquid 1/2 Sabouraud glucose (SG) medium containing $0.5 \%(\mathrm{w} / \mathrm{v})$ Bactopeptone (Difco), $1 \%(\mathrm{w} / \mathrm{v})$ glucose (Merck), $0.001 \%(\mathrm{w} / \mathrm{v}), \mathrm{MgSO}_{4} .7 \mathrm{H}_{2} \mathrm{O}$, and $0.001 \%(\mathrm{w} / \mathrm{v}) \mathrm{KH}_{2} \mathrm{PO}_{4}$ overnight at $30{ }^{\circ} \mathrm{C}$ (exponential cells) on a rotary shaker at 150 r.p.m. in order to culture the fungus in its yeast form, or in YPD liquid medium containing $1 \%(\mathrm{w} / \mathrm{v})$ yeast extract (Oxoid), 1\% (w/v) special peptone (Oxoid), 2\% (w/v) Dglucose (Merk) for $4 \mathrm{~d}$ at $30^{\circ} \mathrm{C}$ (stationary phase) on a rotary shaker at 150 r.p.m. A mutant strain of E. dermatitidis (ATCC 44504), which is defective in the mel3 gene, was obtained from Dr G. Haase (Institut für Medizinische Mikrobiologie, Klinikum RWTH Aachen, Aachen, Germany). Cells were grown overnight at $30^{\circ} \mathrm{C}$ in liquid SG medium containing $1 \%$ $(\mathrm{w} / \mathrm{v})$ Bactopeptone, $1 \%(\mathrm{w} / \mathrm{v})$ glucose and were shaken at 150 r.p.m.

Inhibition of melanin synthesis on solid medium or in liquid medium. Cells were grown on low-pH ascorbate medium plates ( $\mathrm{pH} 3 \cdot 0)$, containing $1 \cdot 17 \%(\mathrm{w} / \mathrm{v}$ ) Bacto yeast carbon base (YCB ; Difco), $0.33 \%(\mathrm{w} / \mathrm{v}$ ) ethylamine. $\mathrm{HCl}$ (Fluka) and $0.8 \%(\mathrm{w} / \mathrm{v})$ agar. Filter-sterilized YCB solution and sterile solutions of ascorbic acid (Merck) (final concentration $0.1 \%$, $\mathrm{w} / \mathrm{v}$ ) were added to autoclaved agar after cooling to $50^{\circ} \mathrm{C}$ (Butler \& Lachance, 1987).

Liquid medium consisted of $1.17 \%(\mathrm{w} / \mathrm{v}$ ) $\mathrm{YCB}$ and $0.33 \%$ $(\mathrm{w} / \mathrm{v})$ ethylamine. $\mathrm{HCl}$. A filter-sterilized solution of ascorbic acid was added to a final concentration of $0 \cdot 1 \%(\mathrm{w} / \mathrm{v})$. The cultures were incubated overnight at $30^{\circ} \mathrm{C}, 150$ r.p.m.

Isolation of cell walls. Cells were isolated by centrifugation for $20 \mathrm{~min}$ at 6000 r.p.m. at $4{ }^{\circ} \mathrm{C}$, and subsequently suspended in $100 \mu \mathrm{g}$ sodium azide $\mathrm{ml}^{-1}$ (Baker Chemicals) and $5 \mu \mathrm{g}$ cycloheximide $\mathrm{ml}^{-1}$ (Fluka). Cells were broken by glass beads and cell walls were isolated from the glass beads and washed three times with $1 \mathrm{M} \mathrm{NaCl}, 1 \mathrm{mM}$ PMSF (Boehringer Mannheim), and subsequently washed with $1 \mathrm{mM}$ PMSF (Montijn et al., 1994).

Isolation of cell wall proteins by extraction with SDS and laminarinase. Cell wall proteins were isolated as previously described (Montijn et al., 1994). Cell walls were boiled in $2 \%$ $(\mathrm{w} / \mathrm{v})$ SDS to isolate SDS-extractable proteins. The supernatant was isolated by centrifugation, and SDS extraction was repeated once for total removal of SDS-extractable proteins (Schreuder et al., 1993). The SDS extract was desalted by gel filtration on a Bio-Gel P-6 polyacrylamide gel column. SDSextracted cell walls were washed three times with $100 \mathrm{mM}$ sodium acetate (BDH), $\mathrm{pH} 5.5,1 \mathrm{mM}$ PMSF, to remove the SDS. To isolate the glucanase-extractable proteins, the washed cell walls were resuspended in the same buffer $(0.5 \mathrm{~g}$ fresh wt $\mathrm{ml}^{-1}$ ) and mollusc laminarinase (Sigma) was added at $0.25 \mathrm{U}$ $(\mathrm{g} \text { cell wall })^{-1}$. After incubation for $2 \mathrm{~h}$ at $35^{\circ} \mathrm{C}$, a further $0.25 \mathrm{U}^{2}$ enzyme ( $\mathrm{g}$ cell wall) ${ }^{-1}$ was added, followed by an additional incubation for $2 \mathrm{~h}$ at $35^{\circ} \mathrm{C}$. The undigested material was pelleted at 14000 r.p.m. for $5 \mathrm{~min}$ and the glucanase-extractable proteins were collected from the supernatant.

Mannoproteins were purified by concanavalin A (ConA)Sepharose affinity chromatography as described by Van Rinsum et al. (1991).

Endo $\mathrm{H}$ digestion. To release high mannose $\mathrm{N}$-chains from cell wall glycoproteins, extracts were digested with Endo $\mathrm{H}$ (endoglycosidase $\mathrm{H}$ recombinant from $E$. coli, Boehringer Mannheim). Forty-microlitre samples of the various extracts containing $3 \%(\mathrm{v} / \mathrm{v}) \beta$-mercaptoethanol and $0.4 \%(\mathrm{w} / \mathrm{v})$ SDS were boiled for $5 \mathrm{~min}$ to denature the proteins; $150 \mu \mathrm{l} 50 \mathrm{mM}$ sodium acetate, $\mathrm{pH} 5 \cdot 5$, containing several protease inhibitors (2 mM EDTA, $1 \mathrm{mM}$ PMSF, $0.42 \%$ pepstatin and $0.3 \%$ leupeptin), and $16 \mu \mathrm{l}$ Endo $\mathrm{H}$ were added. The mixture was incubated overnight at $37^{\circ} \mathrm{C}$. The proteins were precipitated with $90 \%(\mathrm{v} / \mathrm{v})$ ice-cold acetone at $-20^{\circ} \mathrm{C}$ for $2 \mathrm{~h}$, pelleted at 14000 r.p.m. in a cooled Eppendorf centrifuge at $4^{\circ} \mathrm{C}$, and dissolved in $30 \mu \mathrm{l}$ sample buffer. The digested glycoproteins were subjected to SDS-PAGE followed by either silver staining or Western analysis.

Exo- $\alpha$ - or exo- $\beta$-galactosidase treatment of cell wall proteins. Laminarinase extracts were treated with exo- $\alpha$ - or exo- $\beta$ galactosidase (Bahl \& Agrawal, 1969). Acetone-precipitated and freeze-dried proteins were resuspended in $0.05 \mathrm{M}$ citrate buffer (Merck), pH 3.9, and $2 \mu \mathrm{l} \alpha-(20 \mathrm{mU})$ or $\beta-(4 \mathrm{mU})$ galactosidase (from Aspergillus niger, Sigma) were added. 
These samples were incubated at $37^{\circ} \mathrm{C}$ for $1 \mathrm{~h}$. The proteins were precipitated by adding $90 \%(\mathrm{v} / \mathrm{v})$ acetone for $2 \mathrm{~h}$ at $-20{ }^{\circ} \mathrm{C}$, followed by centrifugation in a cooled Eppendorf at $4{ }^{\circ} \mathrm{C}$ at 14000 r.p.m. for $5 \mathrm{~min}$; the supernatants were stored separately.

Carbohydrate analysis. To determine carbohydrate composition the fractions were hydrolysed with $2 \mathrm{M}$ trifluoroacetic acid for $4 \mathrm{~h}$ at $100^{\circ} \mathrm{C}$. Since this results in deacetylation of $\mathrm{N}$ acetylglucosamine, no discrimination between $\mathrm{N}$-acetylglucosamine and glucosamine could be made. The glucosamine detected was referred to as GN. The hydrolysate was lyophilized. The monosaccharide compositions of both fractions were examined by high-pH anion-exchange chromatography with pulsed amperometric detection (Dionex Bio LC Carbohydrate system) as previously described (Montijn et al., 1994).

SDSPAGE and Western blot analysis of cell wall proteins. SDS-PAGE of the cell wall proteins was performed as described previously (Montijn et al., 1994). Proteins were either stained by the silver staining method as described by De Nobel et al. (1989) or transferred electrophoretically to Immobilon PVDF (Millipore) membranes for Western analysis. The membrane was blocked with $5 \%(\mathrm{w} / \mathrm{v})$ non-fat milk powder (Elk, DMV Campina) in PBS [0.8\% (w/v) $\mathrm{NaCl}$ (Merck), $0.02 \%$ (w/v) KCl (Merck), $0.144 \%$ (w/v) $\mathrm{Na}_{2} \mathrm{HPO}_{4}$ (Merck), $0.024 \%(\mathrm{w} / \mathrm{v}) \mathrm{KH}_{2} \mathrm{PO}_{4}$ (Merck)] and incubated with a dilution (1:5000) of affinity-purified 1,6- $\beta$-glucan antibodies (Lu et al., 1995) in PBS/3\% (w/v) BSA. Binding of the antibodies was detected by goat anti-rabbit IgG-peroxidase conjugates (Pierce) and developed using a chemiluminescence detection kit (ECL kit, Western blotting detection reagents, Amersham) as described by Kapteyn et al. (1995). For competitive Western analysis the proteins were transferred to the blot, blocked with PBS $/ 3 \%$ BSA, washed with PBS and incubated with a dilution of the specific antibodies together with $100 \mu \mathrm{M}$ of either pustulan (1,6- $\beta$-glucan; Hoechst) or laminarin (1,3- $\beta$-glucan; Fluka). For the oxidation of 1,6 linkages, mild periodate treatment was performed as described previously (Montijn et al., 1994).

Analytical methods. Protein was assayed with the BCA protein assay reagent (Pierce) with bovine serum albumin as a reference protein. Carbohydrate was measured with phenol/ sulphuric acid (Dubois et al., 1956) with mannose as reference.

Fluorescent labelling of cells. For the fluorescent labelling of whole cells, concanavalin A-fluorescein isothiocyanate (ConA-FITC, Sigma) was used. Cells $(100 \mu \mathrm{l})$ were washed twice with PBS and centrifuged for $30 \mathrm{~s}$ at 14000 r.p.m. Cells were resuspended in $50 \%(\mathrm{v} / \mathrm{v})$ ethanol and washed twice with PBS. After the washing step with ethanol, cells were centrifuged at 3000 r.p.m. for $5 \mathrm{~min}$. After $2 \mathrm{~h}$ incubation in the dark in $10 \%(\mathrm{v} / \mathrm{v})$ ConA-FITC/PBS, cells were washed twice with PBS. Cells were resuspended in PBS and stored in the dark until they were used for microscopy. For microscopic examination an Olympus Automatic Photomicrographic System, model PM-10 ADS, was used and photographs were taken with Kodak Ektachrome 1600 ASA film.

Zymolyase resistance. Zymolyase resistance was expressed as the time needed to decrease the optical density of a cell suspension in the presence of Zymolyase to $50 \%$ of the original value. Cells $\left(10^{7}\right.$ cells) were suspended in $1 \mathrm{ml} 0 \cdot 1 \mathrm{M}$ potassium phosphate $\left(\mathrm{KH}_{2} \mathrm{PO}_{4} / \mathrm{K}_{2} \mathrm{HPO}_{4} ;\right.$ Merck), $\mathrm{pH} 7 \cdot 5$, containing $0.3 \mathrm{mg}$ Zymolyase $20 \mathrm{~T} \mathrm{ml}^{-1}$ at $23^{\circ} \mathrm{C}$. The stock solution of Zymolyase (from Arthrobacter luteus, Seikagaku) was dissolved in $50 \%(\mathrm{v} / \mathrm{v})$ glycerol. $\mathrm{OD}_{530}$ was monitored.

\section{RESULTS}

\section{Inhibition of melanin synthesis by growth on low-pH medium}

Melanin synthesis can be inhibited in the black yeast Phaeococcomyces sp. by growth on a low-pH ascorbate medium (Butler \& Lachance, 1986). To test whether melanin synthesis could also be inhibited in $E$. dermatitidis, wild-type cells were cultured on different media. When wild-type cells were grown on SG medium, they had a typical dark appearance. When grown on a low-pH ascorbate medium, the colonies became significantly less melanized. Similar results were obtained with liquid low-pH ascorbate medium. However, the degree of melanization was still higher than in a non-melanized mel3 mutant.

\section{Zymolyase resistance}

To investigate the possibility of isolating cell wall proteins, wild-type cells and mel 3 mutant cells were treated with Zymolyase, a 1,3- $\beta$-glucanase preparation. Cells were grown on SG and low-pH ascorbate medium. Results varied significantly depending on the degree of melanization. Wild-type cells grown in SG were resistant to Zymolyase treatment. However, wild-type cells became sensitive to Zymolyase when grown in low-pH ascorbate medium. After $28 \mathrm{~min}, 50 \%$ of the cells had lysed as a consequence of cell wall degradation. As expected, mutant cells grown in either medium lysed even more rapidly in the presence of Zymolyase: $50 \%$ of the mel3 cells grown in SG medium had lysed after $11 \mathrm{~min}$, while $50 \%$ of the mel 3 cells grown in low-pH ascorbate medium had already lysed after $8 \mathrm{~min}$. The fact that both wild-type and mutant cells became more sensitive to Zymolyase when grown in low-pH ascorbate medium indicates that in this medium the cell wall is weakened, thereby facilitating cell lysis by Zymolyase. This is also consistent with microscopic observations of the cells. Cells cultured in low-pH ascorbate medium were more spherical and larger than yeast cells grown in SG medium, indicating that the cell wall was indeed weakened (compare Fig. 1c and d).

\section{ConA-FITC labelling of cell walls}

Wild-type cells of E. dermatitidis grown in SG medium were labelled with ConA-FITC and examined by light microscopy. An exponential-phase culture containing mostly yeast cells and some hyphal cells displayed variable labelling intensity. Hyphal elements were fluorescent, while almost no fluorescent yeast cells were detected (Fig. 1a). Stationary-phase yeast cells, however, were moderately labelled (Fig. 1b). Wild-type cells from the exponential phase which had been cultured in low-pH ascorbate medium were moderately labelled (data not shown). Non-melanized mutant yeast cells grown in either normal SG medium or ascorbate medium showed a high intensity of labelling (Fig. 1c and d). Taken together, these data show that the efficiency of 
(a)

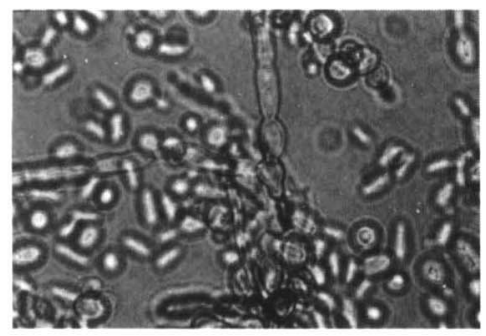

(b)

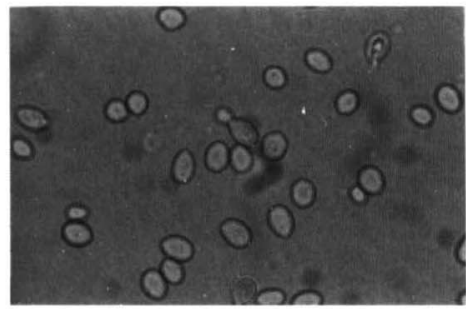

(c)

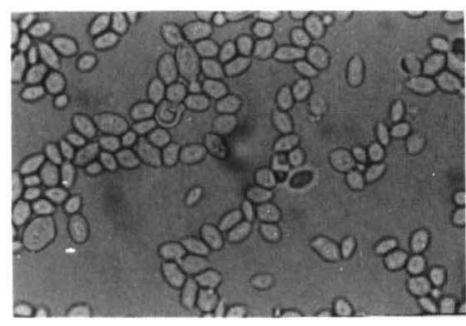

(d)

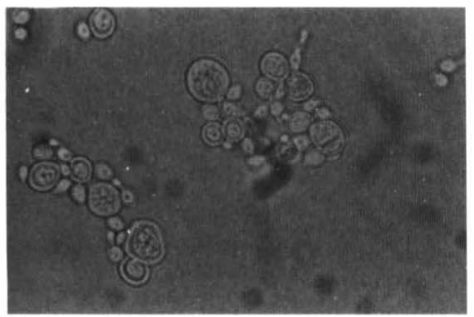

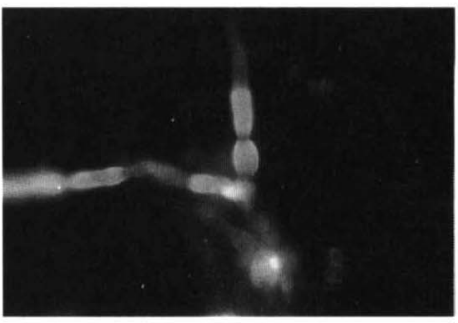
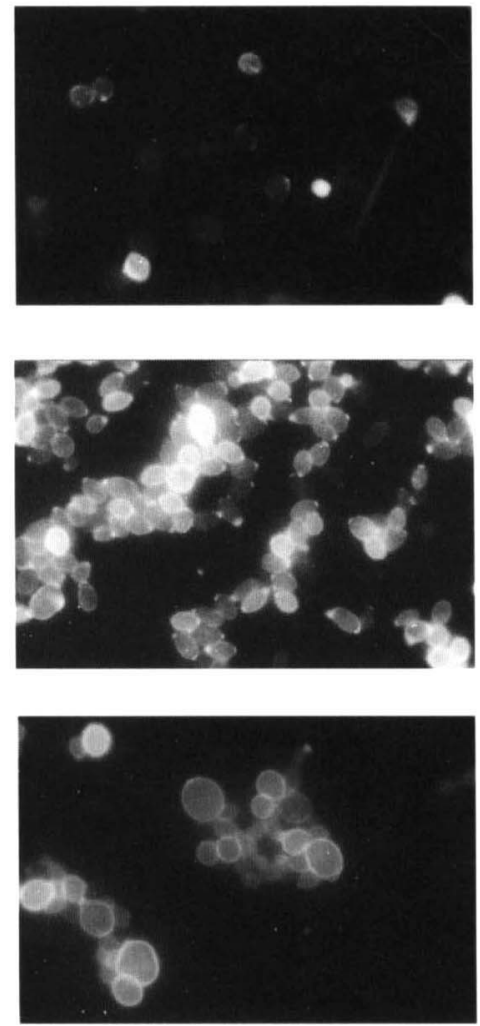

Fig. 1. ConA-FITC labelling. Cells were isolated and labelled with ConA-FITC. Cells on the left side of the figure were photographed with normal light; those on the right side were photographed with fluorescent light. (a) Wild-type cells grown in SG medium isolated in the exponential phase; (b) wild-type cells grown in SG medium isolated in the stationary phase; $(c)$ mutant cells grown in SG medium isolated in the exponential phase; (d) mutant cells grown in low-pH ascorbate medium isolated in the exponential phase.
ConA-FITC labelling of yeast cells is dependent on the growth phase and the degree of melanization.

\section{Composition of the cell wall}

Walls of wild-type and mutant cells consisted of $\mathrm{N}$ acetylglucosamine (or glucosamine, see Methods), galactose, glucose and mannose (Table 1). Walls from mutant cells were isolated and treated with hot SDS and laminarinase for the isolation and characterization of cell wall proteins. Only $10 \%$ of the total cell wall proteins of the mutant cells could be extracted by hot SDS. Since walls from mutant cells were susceptible to glucanase digestion, proteins could be released by laminarinase (a 1,3- $\beta$-glucanase preparation). Carbohydrate analysis demonstrated that the SDS-extractable proteins and laminarinase-extractable proteins contained glucose (Table 1). In S. cerevisiae, glucosylated proteins are exclusively found in glucanase extracts (Van Rinsum et al., 1991; Montijn et al., 1994). The high amount of mannose in both protein fractions is probably derived from $O$ - and $N$-mannosyl chains as found in $S$. cerevisiae. Indeed, proteins in these fractions were sensitive to Endo $\mathrm{H}$, indicating that $\mathrm{N}$-chains are present (Figs 2 and 3), Galactose was also found in both fractions, but no decrease in the amount of galactose could be determined after treatment with $\alpha$ - and $\beta$-exogalactosidase (not shown). Carbohydrate analysis, however (see Methods), revealed an unexpected decrease of the glucose content of these fractions. This result could be explained by contaminating activities in the enzyme preparations used: both $\alpha$ - and $\beta$-galactosidase have minor $\alpha$ - and $\beta$-glucosidase activities (Bahl \& Agrawal, 1969). This implies that galactose is not present in terminal positions of the carbohydrate chains.

\section{Identification of cell wall proteins}

Mutant cells were grown in SG medium. Cell wall proteins were released from isolated cell walls by hot SDS and laminarinase. Laminarinase extracts were purified by ConA-Sepharose affinity chromatography to remove laminarinase (Van Rinsum et al., 1991). Proteins (10 $\mu \mathrm{g}$ per lane) were separated by SDS-PAGE on $2 \cdot 2$ to 
Table 1. Sugar composition of isolated walls and wall proteins from $E$. dermatitidis

\begin{tabular}{|lrrrr|}
\hline Starting material* & \multicolumn{5}{c|}{ Sugar composition (\%) } \\
\cline { 2 - 6 } & GN & Gal & Glc & Man \\
\hline Walls from: & & & & \\
WT (exponential phase) & $1 \cdot 1$ & $4 \cdot 4$ & $55 \cdot 5$ & 39 \\
WT (stationary phase) & $1 \cdot 5$ & $4 \cdot 4$ & $68 \cdot 1$ & 26 \\
mel3 (exponential phase) & 0.5 & $5 \cdot 5$ & 67 & 27 \\
Proteins† from: & & & & \\
mel3 (SDS extract) & 0.6 & $8 \cdot 8$ & 6.6 & 84 \\
mel3 (glucanase extract) & 0.3 & $34 \cdot 6$ & $2 \cdot 1$ & 63 \\
\hline
\end{tabular}

"WT, wild-type cells; mel3, non-melanized mutant cells.

†Proteins were purified by ConA-Sepharose affinity chromatography.

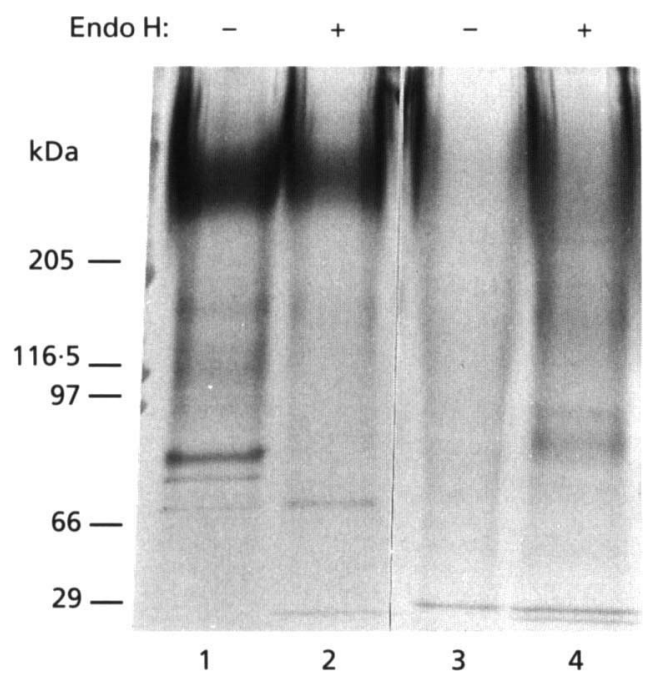

Fig. 2. Protein profiles of various cell wall fractions of the nonmelanized mutant of $E$. dermatitidis. Lanes 1 and 2, SDSextractable proteins; lanes 3 and 4 , laminarinase-extractable proteins. The extracts in lanes 2 and 4 were digested with Endo $\mathrm{H}$. Proteins were separated by SDS-PAGE $(2 \cdot 2-20 \%)$ and visualized by silver staining. Molecular masses are indicated in kDa.

$20 \%$ gradient gels and visualized by silver staining (Fig. 2 ). The SDS extract of the mutant contained a major protein with a mean molecular mass of $335 \mathrm{kDa}$ and less abundant proteins with lower molecular masses (lane 1). No major Endo-H-sensitive SDS-extractable proteins could be detected in this experiment (lane 2), but some minor bands disappeared after Endo $\mathrm{H}$ digestion. However, Endo $\mathrm{H}$-sensitive proteins could be detected when this fraction was analysed by Western analysis using purified 1,6- $\beta$-glucan antibodies (Fig. 3).

Laminarinase extracts of the mutant grown in SG medium were also analysed by SDS-PAGE. Although

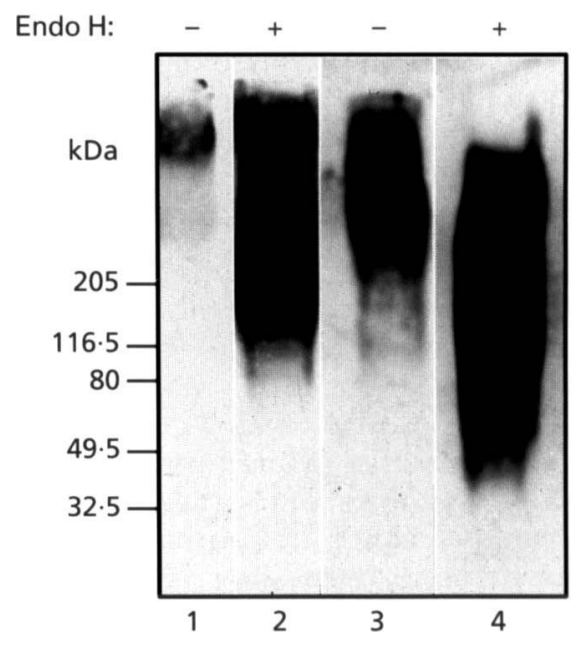

Fig. 3. Western analysis of cell wall proteins using affinity purified 1,6- $\beta$-glucan antibodies at a serum dilution of 1:5000. Binding of the antibodies was detected with a goat anti-rabbit IgG-peroxidase conjugate. Lanes 1 and 2, SDS-extractable proteins; lanes 3 and 4, laminarinase-extractable proteins. The extracts in lanes 2 and 4 were digested with Endo $\mathrm{H}$. Molecular masses are indicated in $\mathrm{kDa}$.

sufficient laminarinase-extracted proteins of cells grown in SG were loaded on the gel, not many proteins could be visualized by silver staining (Fig. 3, lane 3). Faint lowmolecular-mass bands were detected. After Endo $\mathrm{H}$ treatment a high molecular mass smear became visible (lane 4). A low-molecular-mass band of $71 \mathrm{kDa}$ was also detected. These proteins probably originated from hypermannosylated proteins of highly variable molecular mass that only gave rise to visible bands after Endo $\mathrm{H}$ treatment. This phenomenon has previously been demonstrated for laminarinase extracts of Candida albicans (Kapteyn et al., 1994).

\section{Identification of $1,6-\beta$-glucan side chains on cell wall proteins}

Recently, it was shown by SDS-PAGE and Western analysis that laminarinase-extractable cell wall proteins of $S$. cerevisiae and C. albicans contain 1,6- $\beta$-glucan side-chains (Montijn et al., 1994; Kapteyn et al., 1994). Protein extracts of E. dermatitidis mutant cell walls were subjected to Western analysis using affinitypurified anti-1,6- $\beta$-glucan serum to test whether $1,6-\beta$ glucosylated proteins could also be detected in $E$. dermatitidis. In the SDS extract of mutant cells a smear with a molecular mass $>390 \mathrm{kDa}$ was recognized by the antibodies (Fig. 3, lane 1). The major protein of $335 \mathrm{kDa}$ visualized by silver staining (Fig. 2, lanes 1 and 2) was not recognized by the antibodies, indicating that only a part of the SDS-extractable protein carries $1,6-\beta$ glucan. After Endo $\mathrm{H}$ digestion, the antibodies revealed a polydisperse smear with a lower molecular mass (lane $2)$. This demonstrated that $N$-chains were released. As the 1,6- $\beta$-glucan signal did not decrease in strength, this 
indicated that the $1,6-\beta$-glucan chains were resistant to Endo $\mathrm{H}$ digestion. Laminarinase digests of the mutant showed a heavily labelled smear ranging in mass from 80 to $>500 \mathrm{kDa}$ (Fig. 3, lane 3). After Endo H treatment, the mobility of these glucosylated proteins was reduced to a smear with a molecular mass of 40 to $450 \mathrm{kDa}$ (lane 4).

To confirm that the epitope on the proteins contained $1,6-\beta$-glucose residues, the following control experiments were carried out. In a competitive Western analysis, $100 \mu \mathrm{M}$ pustulan (a 1,6- $\beta$-glucan) inhibited the binding of the antibodies (Montijn et al., 1994), whereas laminarin a (1,3- $\beta$-glucan) did not significantly affect the binding, even at a concentration of $200 \mu \mathrm{M}$ (data not shown). Furthermore, it was shown that the epitope was sensitive to oxidation by periodate, consistent with the notion that the epitope was composed of 1,6 -linked carbohydrates (data not shown).

\section{DISCUSSION}

The cell wall of E. dermatitidis is composed of carbohydrates, glycoproteins and melanin. Carbohydrate analysis demonstrated that the wall consisted of glucose, $(\mathrm{N}$-acetyl)glucosamine, mannose and galactose. To explore the possibility of extracting cell wall proteins by $1,3-\beta$-glucanase digestion, cells were subjected to a Zymolyase-resistance assay. Melanized wild-type yeast cells resisted the lytic effect of Zymolyase, a 1,3- $\beta$ glucanase preparation. However, when wild-type cells were grown on low-pH ascorbate medium, melanin synthesis was partly inhibited and the 'albinized' cells became less resistant to Zymolyase. This is in agreement with Butler \& Lachance (1986) who demonstrated that albinized cells of the black yeast Phaeococcomyces sp. became sensitive to Zymolyase. Non-melanized mel3 mutants were even more sensitive to Zymolyase digestion, confirming that the sensitivity for Zymolyase is dependent on the degree of melanization. However, it was also shown that mutant cells grown in low-pH ascorbate medium were more sensitive to Zymolyase than mutant cells grown in SG medium. This indicates that the composition of the cell wall is dependent on the culture medium as was shown previously for S. cerevisiae (McMurrough \& Rose, 1967).

In $S$. cerevisiae it has been shown that mannan in the wall is, at least partially, exposed on the outside, since the wall reacts strongly with ConA (Tkacz et al., 1971; Ballou, 1982; Frevert \& Ballou, 1985; Kukuruzinska et al., 1987; Pringle et al., 1989). In E. dermatitidis, melanin seems to mask the mannoproteins of the cell wall, since wild-type exponential-phase yeast cells could not be labelled by ConA-FITC (Fig. 1a), whereas some labelling was obtained with albinized wild-type yeast cells (not shown). Non-melanized mutant cells labelled very well. In contrast to wild-type yeast cells, wild-type hyphal elements showed a high intensity of fluorescence. Stationary-phase yeast cells of the wild-type displayed a moderate labelling with ConA-FITC. Two explanations are possible for these observations: (i) the manno- proteins in hyphal cells or in the stationary phase of yeast cells are not masked by melanin, or (ii) an extracellular polysaccharide capsule, which is composed of $\alpha$-glucan and can also be recognized by ConA, is formed in these cells (Kwon-Chung et al., 1992; De Hoog et al., 1995).

Since wild-type cells of $E$. dermatitidis were resistant to Zymolyase, mel 3 mutants were used for the isolation and characterization of cell wall proteins. In glucanase extracts and in SDS extracts, proteins containing mannose, galactose, ( $\mathrm{N}$-acetyl)glucosamine, and glucose were found. Western analysis revealed that at least part of the glucose present in both extracts was 1,6 - $\beta$-linked (Fig. 3). This is in contrast to $S$. cerevisiae, where SDSsoluble cell wall proteins are not 1,6- $\beta$-glucosylated ( $\mathrm{Lu}$ et al., 1995; Montijn et al., 1994). Addition of 1,6- $\beta$ glucan to the cell wall proteins is correlated with their incorporation (van Berkel et al., 1994). Kapteyn et al. (1996) have shown that cell wall proteins were crosslinked to $1,3-\beta$-glucan through their 1,6- $\beta$-glucan moiety. Possibly, the presence of 1,6- $\beta$-glucosylated proteins in the SDS extract of Exophiala is caused by an accumulation of cell wall precursors which are not yet linked to 1,3- $\beta$-glucan. If pulse-chase experiments could support this hypothesis, the 1,6- $\beta$-glucosylated SDSextractable proteins would provide an excellent tool for cross-linking studies.

The presence of 1,6- $\beta$-glucosylated proteins is not unique to $E$. dermatitidis. $1,6-\beta$-Glucosylated proteins have been found in other ascomycetes such as the 'classical' yeast S. cerevisiae (Montijn et al., 1994), the dimorphic yeast Candida albicans (Kapteyn et al., 1994, 1995, 1996), the yeast Hansenula polymorpha $(\mathrm{H}$. Caro, personal communication), and in the 'true' filamentous fungus Fusarium oxysporum (Schoffelmeer et al., 1996). This indicates that this type of linkage is a general phenomenon among ascomycetes.

\section{REFERENCES}

Bahl, P. \& Agrawal, K. M. L. (1969). Glycosidases of Aspergillus niger. Purification and characterization of $\alpha$ - and $\beta$-galactosidases and $\beta$ - $N$-acetylglucosaminidase. J Biol Chem 244, 2970-2978.

Ballou, C. E. (1982). Yeast cell wall and cell surface. In The Molecular Biology of the Yeast Saccharomyces: Metabolism and Gene Expression, pp. 335-360. Edited by J. N. Strathern, E. W. Jones \& J. R. Broach. Cold Spring Harbor, NY: Cold Spring Harbor Laboratory.

Ballou, C. E. (1990). Isolation, characterization, and properties of Saccharomyces cerevisiae $m n n$ mutants with nonconditional protein glycosylation defects. Methods Enzymol 185, 440-470.

Blaschke-Hellmessen, R., Lauterbach, I., Paul, K.-D., Tintelnot, K. \& Weißbach, G. (1994). Isolation of Exophiala dermatitidis (Kano) De Hoog 1977 from a child with septicaemia in acute lymphatic leukaemia and from patients with cystic fibrosis. Mycoses 37 (Suppl. 1), 89-96.

Butler, M. J. \& Lachance, M. A. (1987). Inhibition of melanin synthesis in the black yeast Phaeococcomyces sp. by growth on low $\mathrm{pH}$ ascorbate medium: production of spheroplasts from 'albinized' cells. Can J Microbiol 33, 184-187. 
Crosby, J. H., O’Quinn, M. H., Steele, J. C. H. \& Rao, R. N. (1989). Fine-needle aspiration of subcutaneous phaeohyphomycosis caused by Wangiella dermatitidis. Diagn Cytopathol 5, 293-297.

De Hoog, G. S. \& Guarro, J. (editors) (1995). Atlas of Clinical Fungi. Baarn/Tarragonà: Centraalbureau voor Schimmelcultures/Universitat Rovira i Virgili.

De Hoog, G. S., Gerrits van den Ende, A. H. G., Uijthof, J. M. J. \& Untereiner, W. A. (1995). Nutritional physiology of type isolates of currently accepted species of Exophiala and Phaeococcomyces. Antonie Leeuwenhoek 68, 43-50.

De Nobel, J. G., Dijkers, C., Hooijberg, E. \& Klis, F. M. (1989). Increased cell wall porosity in Saccharomyces cerevisiae after treatment with dithiothreitol or EDTA. J Gen Microbiol 135, 2077-2084.

Dixon, D. M., Polak, A. \& Szaniszlo, P. J. (1987). Pathogenicity and virulence of wild-type and melanin-deficient Wangiella dermatitidis. J Med Vet Mycol 25, 97-106.

Dixon, D. M., Polak, A. \& Conner, G. W. (1989). mel $^{-}$mutants of Wangiella dermatitidis in mice: evaluation of multiple mouse and fungal strains. J Med Vet Mycol 27, 335-341.

Dixon, D. M., Szaniszlo. P. J. \& Polak, A. (1991). Dihydroxynaphthalene (DHN) melanin and its relationship with virulence in the early stages of phaeohyphomycosis. In The Fungal Spore and Disease Initiation in Plants and Animals, pp. 297-318. Edited by G. T. Cole \& H. C. Hoch. New York: Plenum Press.

Dixon, D. M., Migliozzi, J., Cooper, C. R., Jr, Solis, O., Breslin, B. \& Szaniszlo, P. J. (1992). Melanized and non-melanized multicellular form mutants of Wangiella dermatitidis in mice: mortality and histopathology studies. Mycoses 35, 17-21.

Dubois, M., Gilles, K. A., Hamilton, J. K., Rebers, P. A. \& Smith, F. (1956). Colorimetric method for determination of sugars and related substances. Anal Chem 28, 350-356.

Fleet, G. H. (1991). Cell walls. In The Yeasts, 2nd edn, vol. 4, Yeast Organelles, pp. 199-277. Edited by A. H. Rose \& J.S. Harrison. London: Academic Press.

Frevert, J. \& Ballou, C. E. (1985). S. cerevisiae structural cell wall mannoproteins. Biochemistry 24, 753-759.

Geis, P. A. (1981). Chemical composition of the yeast and sclerotic cell walls of Wangiella dermatitidis. PhD thesis, University of Texas.

Geis, P. A. \& Szaniszlo, P. J. (1984). Carotenoid pigments of the dematiaceous fungus Wangiella dermatitidis. Mycologia 76, 268-273.

Haase, G., Skopnik, H., Groten, T., Kusenbach, G. \& Posselt, H. G. (1991). Long-term fungal cultures from patients with cystic fibrosis. Mycoses 34, 373-376.

Hård, K., Bitter, W., Kamerling, J. P. \& Vliegenthart, J. F. G. (1989). O-Mannosylation of recombinant human insulin-like growth factor I (IGF-I) produced in Saccharomyces cerevisiae. FEBS Lett 248, 111-114.

Herscovics, A. \& Orlean, P. (1993). Glycoprotein biosynthesis in yeast. FASEB J 7, 540-550.

Hiruma, M., Kawada, A., Ohata, T., Ohnishi, Y., Takahashi, H., Yamazaki, M., Ishibashi, A., Hatsuse, K., Kakihara, M. \& Yoshida, M. (1993). Systemic phaeohyphomycosis caused by Exophiala dermatitidis. Mycoses 36, 1-7.

Hohl, P. E., Holley, H. P., Prevost, E., Ajello, L. \& Padhye, A. A. (1983). Infections due to Wangiella dermatitidis in humans. Rev Infect Dis 5, 854-864.

Kabel, P. J., Illy, K. E., Holl, R. A., Buiting, A. G. M. \& Wintermans,
R. G. F. (1994). Nosocomial intravascular infection with Exophiala dermatitidis. Lancet 344, 1167-1168.

Kapteyn, J. C., Montijn, R. C., Dijkgraaf, G. J. P. \& Klis, F. M. (1994). Identification of $\beta$-1,6-glucosylated cell wall proteins in yeast and hyphal forms of Candida albicans. Eur J Cell Biol 65, $402-407$.

Kapteyn, J. C., Montijn, R. C., Dijkgraaf, G. J. P., Van Den Ende, H. \& Klis, F. M. (1995). Covalent association of $\beta$-1,3-glucan with $\beta$ 1,6-glucosylated mannoproteins in cell walls of Candida albicans. $J$ Bacteriol 177, 3788-3792.

Kapteyn, J. C., Montijn, R. C., Vink, E., De La Cruz, J., Llobell, A., Douwes, J. E., Shimoi, H., Lipke, P. N. \& Klis, F. M. (1996). Retention of Saccharomyces cerevisiae cell wall proteins through a phosphodiester-linked $\beta$-1,3-/ $\beta$-1,6-glucan heteropolymer. Glycobiology 6, 337-345.

Klis, F. M. (1994). Cell wall assembly in yeast. Yeast 10, 851-869. Kukuruzinska, M. A., Bergh, M. L. E. \& Jackson, B. J. (1987). Protein glycosylation in yeast. Annu Rev Biochem 56, 915-944.

Kusenbach, G., Skopnik, H., Haase, G., Friedrichs, F. \& Doehmen, H. (1992). Exophiala dermatitidis pneumonia in cystic fibrosis. Eur J Pediatr 151, 344-346.

Kwon-Chung, K. J. \& Bennett, J. W. (1992). Medical Mycology. Philadelphia: Lea \& Febiger.

Lu, C. F., Kurjan, J. \& Lipke, P. N. (1994). A pathway for cell wall anchorage of Saccharomyces cerevisiae $\alpha$-agglutinin. Mol Cell Biol 14, 4825-4833.

Lu, C. F., Montijn, R. C., Brown, J. L., Klis, F. M., Kurjan, J., Bussey, H. \& Lipke, P. N. (1995). Glycosyl phosphatidylinositol-dependent cross-linking of $\alpha$-agglutinin and $\beta$-1,6-glucan in the Saccharomyces cerevisiae cell wall. J Cell Biol 128, 333-340.

Matsumoto, T., Padhye, A. A., Ajello, L., Standard, P. G. \& McGinnis, M. R. (1984). Critical review of human isolates of Wangiella dermatitidis. Mycologia 76, 232-249.

Matsumoto, T., Matsuda, T., McGinnis, M. R. \& Ajello, L. (1993). Clinical and mycological spectra of Wangiella dermatitidis infections. Mycoses 36, 145-155.

McMurrough, I. \& Rose, A. H. (1967). Effect of growth rate and substrate limitation on the composition and structure of the cell wall of Saccharomyces cerevisiae. Biochem J 105, 189-203.

Montijn, R. C., van Rinsum, J., van Schagen, F. A. \& Klis, F. M. (1994). Glucomannoproteins in the cell wall of Saccharomyces cerevisiae contain a novel type of carbohydrate side chain. J Biol Chem 269, 19338-19342.

Pastor, F. I. J., Valentin, E., Herrero, E. \& Sentandreu, R. (1984). Structure of the $S$. cerevisiae cell wall: mannoproteins released by zymolyase and their contributions to wall architecture. Biochim Biophys Acta 802, 292-300.

Polak, A. (1989). Melanin as a virulence factor in pathogenic fungi. Mycoses 33, 215-224.

Polak, A. \& Dixon, D. M. (1993). Pathogenicity of Wangiella dermatitidis. In Dimorphic Fungi in Biology and Medicine, pp. 307-312. Edited by H. Van den Bossche, F. C. Odds \& D. Kerridge. New York: Plenum Press.

Pringle, J. R., Preston, R. A., Adams, A. E. M., Stearns, T., Drubin, D. G., Haarer, B. K. \& Jones, E. W. (1989). Fluorescence microscopy methods for yeast. Methods Cell Biol 31, 357-435.

Roemer, T., Delaney, S. \& Bussey, H. (1993). SKN1 and KRE6 define a pair of functional homologs encoding putative membrane proteins involved in $\beta$-glucan synthesis. Mol Cell Biol 13, $4039-4048$. 
Schoffelmeer, E., Kapteyn, J. C., Montijn, R. C., Cornelissen, B. C. \& Klis, F. M. (1996). Glucosylation of fungal cell wall proteins as a potential target for novel anti-fungal agents. In Modern Fungicides and Antifungal Compounds. Edited by H. Lyr, P. E. Russel \& H. D. Sisler. Hampshire, UK: Intercept.

Schreuder, M. P., Brekelmans, S., Van Den Ende, H. \& Klis, F. M. (1993). Targeting of a heterologous protein to the cell wall of Saccharomyces cerevisiae. Yeast 9, 399-409.

Szaniszlo, P. J., Geis, P. A., Jacobs, C. W., Cooper, C. R. \& Harris, J. L. (1983). Cell wall changes associated with yeast-tomulticellular form conversion in Wangiella dermatitidis. In Microbiology-1983, pp. 239-244. Edited by D. Schlessinger. Washington, DC: American Society for Microbiology.

Taylor, B. E., Wheeler, M. H. \& Szaniszlo, P. J. (1987). Evidence for pentaketide melanin biosynthesis in dematiaceous human pathogenic fungi. Mycology 79, 320-322.

Tkacz, J. S., Cybulska, B. \& Lampen, J. O. (1971). Specific staining of wall mannan in yeast cells with fluorescein-conjugated concanavalin A. J Bacteriol 105, 1-5.
Uijthof, J. M. J., De Hoog, G. S., De Cock, A. W. A. M., Takeo, K. \& Nishimura, K. (1994). Pathogenicity of strains of the black yeast Exophiala (Wangiella) dermatitidis: an evaluation based on polymerase chain reaction. Mycoses 37, 235-242.

Van Berkel, M. A. A., Caro, L. H. P., Montijn, R. C. \& Klis, F. M. (1994). Glucosylation of chimeric proteins in the cell wall of Saccharomyces cerevisiae. FEBS Lett 349, 135-138.

Van Der Vaart, J. M., Caro, L. H. P., Chapman, J. W., Klis, F. M. \& Verrips, C. T. (1995). Identification of three mannoproteins in the cell wall of Saccharomyces cerevisiae. J Bacteriol 177, 3104-3110.

Van Rinsum, J., Klis, F. M. \& Van den Ende, H. (1991). Cell wall glucomannoproteins of Saccharomyces cerevisiae mnn9. Yeast 7 , 717-726.

Zueco, J., Mormeneo, S. \& Sentandreu, R. (1986). Temporal aspects of the $\mathrm{O}$-glycosylation of $S$. cerevisiae mannoproteins. Biochim Biophys Acta 248, 93-100.

Received 10 September 1996; revised 6 December 1996; accepted 16 December 1996. 